\title{
HIV-1 is budded from CD4+ T lymphocytes independently of exosomes
}

In-Woo Park ${ }^{1,2}$, Johnny J He ${ }^{1,2^{*}}$

\begin{abstract}
The convergence of HIV-1 budding and exosome biogenesis at late endosomal compartments called multivesicular bodies has fueled the debate on whether HIV-1 is budded from its target cells and transmitted in the form of exosomes. The point of contention appears to primarily derive from the types of target cells in question and lack of a well-defined protocol to separate exosomes from HIV-1. In this study, we adapted and established a simplified protocol to define the relationship between HIV-1 production and exosome biogenesis. Importantly, we took advantage of the newly established protocol to unequivocally show that HIV-1 was produced from CD4+ T lymphocytes Jurkat cells independently of exosomes. Thus, this study not only presents a simplified way to obtain highly purified HIV-1 virions for identification of host proteins packaged into virions, but also provides a technical platform that can be employed to define the relationship between exosome biogenesis and budding of HIV-1 or other viruses and its contributions to viral pathogenesis.
\end{abstract}

\section{Text}

Exosomes were initially identified as small membrane vesicles from immature red blood cells [1] and have since been detected in various mammalian cells, tissues and physiological fluids [see a recent review [2]]. They are originated from multivesicular bodies through direct fusion with plasma membrane $[3,4]$, with sizes ranging between 30 and $100 \mathrm{~nm}[5,6]$. Several important functions have been attributed to these small vesicles, these include protein homeostasis [7], humoral immune response [5,8-10], cell-cell interaction [11,12], and antitumor activity [6]. In addition, exosomes have also been proposed to play an important role in HIV-1 budding and infection [13], as exosomes and HIV-1 converge at the endosomes and share similar host lipid and protein compositions $[10,14]$. In macrophages and dendritic cells, HIV-1 was shown to bud into the endosomes [15-20] and secreted in the form of exosomes [21-23]. Recently, a consensus has emerged that HIV-1 does not bud into endosomes but to an external compartment $[24,25]$. To the contrary, the findings in $\mathrm{CD} 4+\mathrm{T}$ lymphocytes are quite inconsistent and uncertain. Some studies suggest that HIV-1 is budded from $\mathrm{T}$ cell plasma membrane and

\footnotetext{
* Correspondence: jjhe@iupui.edu

'Department of Microbiology and Immunology, Indiana University School of Medicine, Indianapolis, IN 46202, USA

Full list of author information is available at the end of the article
}

does not involve endosomes and exosomes [26-31], while others show that $\mathrm{T}$ cells produce HIV-1 in close association with exosomes, similarly to that in macrophages and dendritic cells [32-34]. The inconsistency concerning the relationship between HIV-1 budding and exosome biogenesis conceivably is likely due to cross-contamination of each other during isolation and purification as a result of their indistinguishable sizes and densities [35,36]. Thus, to define the precise role of exosomes in HIV-1 budding, transmission and other virol-immunological processes, it is imperative to establish a simplified and reproducible protocol that allows clear separation of exosomes from HIV-1.

Several ways have been exploited to study HIV-1 interaction with exosomes. The general approach is a step-wise protocol, which is composed of first brief lowspeed centrifugation to remove cells and cell debris from the cell culture supernatant, then filtration by passing the cleared through a $0.22 \mathrm{~nm}$ filter, and lastly high-speed centrifugation to obtain exosomes and/or HIV-1 virions. The presence of exosomes, HIV-1, or both is evaluated by detection of exosome markers, and HIV-1 viral antigens, and electron microscopic imaging. In this study, we introduced a modified protocol that allows successful separation of HIV-1 virions from exosomes. Similar protocols have been widely employed to isolate or concentration HIV-1 virions. 
Briefly, Jurkat cells were infected with HIV-1 HXB2 viruses equivalent to $10,000 \mathrm{cpm}$ reverse transcriptase (RT) activity and cultured for 7-9 days when virus replication was peaked (data not shown). The cell culture supernatant was collected and first centrifuged at $800 \mathrm{~g}$ for $10 \mathrm{~min}$ to remove cells and cell debris. The cleared supernatant was then passed through a $0.22 \mu \mathrm{m}$ filter (Corning, NY) to ensure complete removal of smaller cell debris. The pass-through supernatant was loaded onto $1 \mathrm{ml} 20 \%$ sucrose in PBS and centrifuged with a SW55Ti (Beckman, NY) at 238,000 $g$ for 90 min to obtain the virion preparation (S). To compare virion compositions, a same volume of the cleared supernatant from the first centrifugation and the pass-through from the filtration was loaded onto $1 \mathrm{ml} \mathrm{PBS}$ and subjected to the same last step high-speed centrifugation to obtain virion preparation $C$ and $F$, respectively. All three virion preparations were suspended in the SDS-PAGE sample buffer for Western blot analysis. Using the highly abundant $\beta$-actin protein as an exosomal marker $[2,37,38]$, we detected exosomes in virion preparations $\mathrm{C}$ and $\mathrm{F}$, but not in virion preparation $\mathrm{S}$ (Figure 1A). Importantly, we detected a comparable level of HIV-1 p24 in all three virion preparations (Figure 1A), as well as a comparable level of RT activity among all three virion preparations (Figure 1B). These results together show that the high-speed centrifugation with the $20 \%$ sucrose cushion at the last step gives rise to HIV-1 virions

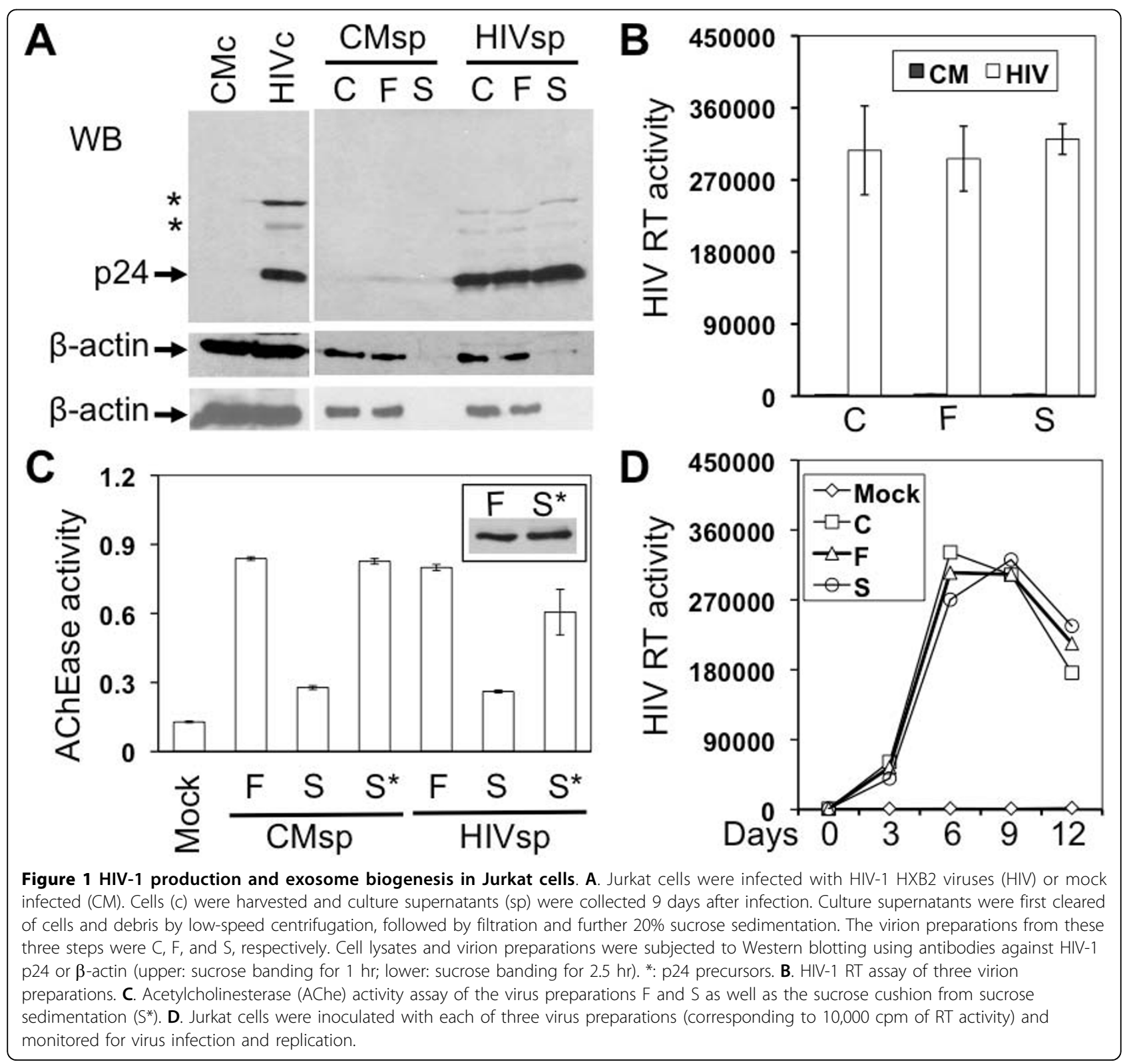


completely free of exosomes, refuting the HIV-1 Trojan exosome hypothesis. We also included the lysates from HIV-1-infected Jurkat cells (HIVc) and mock-infected Jurkat cells (CMc), as well as the pellets of supernatants from mock-infected Jurkat cells (CMsp), as controls in the experiments. Longer high-speed centrifugation at the last step, i.e., $2.5 \mathrm{hr}$, did not change the $\beta$-actin distribution pattern (bottom, Figure 1A).

To confirm that the new protocol did lead to successful separation of HIV-1 virions from exosomes, we further analyzed virion preparations $\mathrm{F}$ and $\mathrm{S}$ for the presence of exosomes using the other well-documented exosome marker, acetylcholinesterase (AChe) $[1,31]$. We found a significant level of AChe activity in virion preparation $\mathrm{F}$ but a much lower level of AChe activity in virion preparation $\mathrm{S}$ (Figure 1C). The Ache activity in preparation $\mathrm{F}$ and $\mathrm{S}$ showed little changes between the mock- and HIV-1infected samples. To ensure that exosomes were completely separated from HIV-1 virions and thereby remained in the sucrose cushion $\left(\mathrm{S}^{*}\right)$, we further analyzed the AChe activity in the sucrose cushion and detected a level of AChe activity in the sucrose cushion comparable to that in preparation $\mathrm{F}$ (Figure 1C), verifying a clear separation of HIV-1 from exosomes by the new protocol. This was further supported by Western blotting analysis that $\beta$-actin was detected in preparation $S^{*}$ with a comparable intensity to that in preparation $\mathrm{F}$ in mock-infected samples, indicating that almost all exosomes in preparation $\mathrm{F}$ were separated from virions and recovered in preparation $S^{*}$ (Insert in Figure 1C). We obtained similar results from HIV-infected samples (data not shown). Using another exosome marker, heat shock protein 70 (Hsp70) [38-41], we also obtained similar results (data not shown). To further ascertain independent release of HIV-1 virions from exosomes, we fixed and negative stained both $\mathrm{F}$ and $\mathrm{S}$ virion preparations and visualized them using transmission electron microscopy. Preparation F contained particles of at least three different sizes: 80-120 nm HIV-1 virions (closed arrowhead), 30-100 nm irregularly shaped exosomes (open arrowhead), and larger other membrane vesicles (arrow) (Figure $2 \mathrm{~A}$ ), with about $83.7 \pm 4.3 \%$ exosomes and $15.8 \pm 3.2 \%$ HIV-1 virions from a total of eight randomly selected EM fields in multiple EM images. In comparison, preparation S had 80 - $120 \mathrm{~nm}$ HIV-1 virions free of any sizes of membrane vesicles (Figure 2B), with $4.3 \pm 3.2 \%$ exosomes and $93.5 \pm 5.7 \%$ HIV -1 virions. Furthermore, we determined whether there were any differences in the infectivity of these three virion preparations. To this end, we infected Jurkat cells with each of the viruses of the same amount of RT activity and monitored virus infection and replication in these cells. There were little differences of viral replication kinetics among these three virion preparations (Figure 1D). Thus, unlike the findings from dendritic cells that exosomes-associated HIV-1 virions are more infectious [21], these results indicate that the presence of exosomes does not affect the HIV-1 infectivity in Jurkat cells.

In summary, all these experiments show that HIV-1 virions obtained from the new protocol are free of exosomes and provide conclusive evidence that HIV-1 budding and exosome secretion in Jurkat cells are independent from each other. Of note are two other published protocols that have also been shown to produce exosomes-free HIV-1 virions. One involves use of

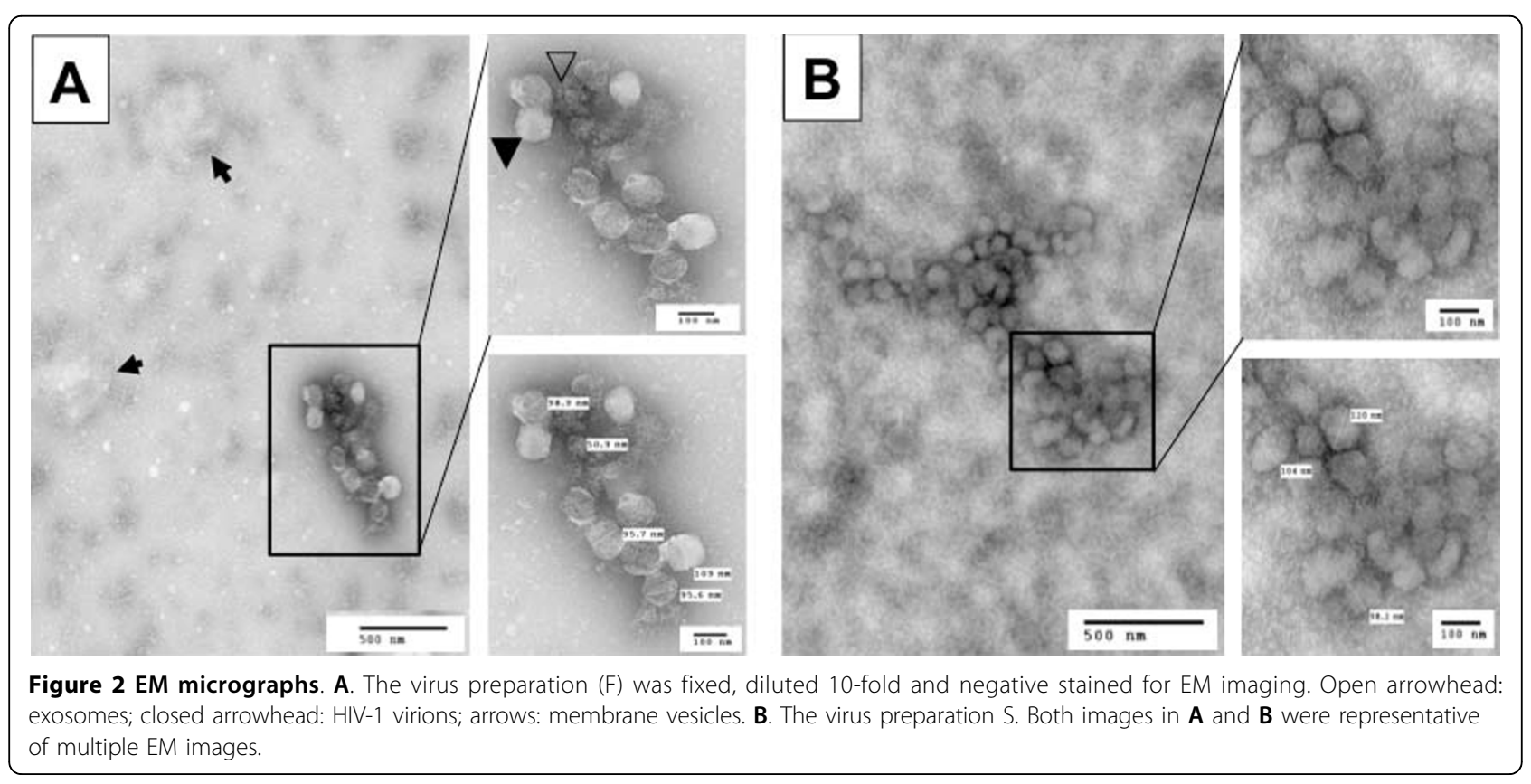


iodixanol gradient sedimentation followed by fractionation [31]. Besides its requirement of the special agent iodixanol, the fractionation manipulation in this protocol is quite laborious. The other protocol is to use CD45 magnetic beads to deplete CD45-containing exosomes from HIV-1 virion preparations [28]. This protocol is clearly not applicable to analysis of exosomes and HIV-1 virions produced from cells that express little or no CD45. Thus, this study not only presents a simplified way to obtain highly purified HIV-1 virions free of exosomes or other cellular vesicles for basic HIV-1 virological studies, but also provides a technical platform that can be employed to further define the relationship between HIV-1 budding and exosome biogenesis in other HIV-1 target cells such as macrophages and dendritic cells and its contributions to HIV-1 pathogenesis.

\section{Acknowledgements}

This work was supported in part by the grants R01MH065158 and R21DA029428 (to JJH) from the National Institutes of Health.

\section{Author details}

'Department of Microbiology and Immunology, Indiana University School of Medicine, Indianapolis, IN 46202, USA. ${ }^{2}$ Center for AIDS Research, Indiana University School of Medicine, Indianapolis, IN 46202, USA.

\section{Authors' contributions}

IWP designed, performed experiments and prepared the manuscript; JJH designed and prepared the manuscript. Both authors read and approved the final version of the manuscript.

\section{Authors' information}

In-Woo Park, Ph.D., Assistant Research Professor, Center for AIDS Research and Department of Microbiology and Immunology Indiana University School of Medicine, Indianapolis, IN 46202, USA

Johnny J. He, Ph.D., Professor and Director, Center for AIDS Research and Department of Microbiology and Immunology Indiana University School of Medicine, Indianapolis, IN 46202, USA

\section{Competing interests}

The authors declare that they have no competing interests.

Received: 5 August 2010 Accepted: 16 September 2010 Published: 16 September 2010

\section{References}

1. Johnstone RM, Adam M, Hammond JR, Orr L, Turbide C: Vesicle formation during reticulocyte maturation. Association of plasma membrane activities with released vesicles (exosomes). J Biol Chem 1987, 262:9412-9420.

2. Simpson RJ, Jensen SS, Lim JW: Proteomic profiling of exosomes: current perspectives. Proteomics 2008, 8:4083-4099.

3. Pan BT, Johnstone RM: Fate of the transferrin receptor during maturation of sheep reticulocytes in vitro: selective externalization of the receptor. Cell 1983, 33:967-978.

4. Stoorvogel W, Kleijmeer MJ, Geuze HJ, Raposo G: The biogenesis and functions of exosomes. Traffic 2002, 3:321-330.

5. Raposo G, Nijman HW, Stoorvogel W, Liejendekker R, Harding CV, Melief CJ, Geuze HJ: B lymphocytes secrete antigen-presenting vesicles. J Exp Med 1996, 183:1161-1172.

6. Zitvogel L, Regnault A, Lozier A, Wolfers J, Flament C, Tenza D, RicciardiCastagnoli P, Raposo G, Amigorena S: Eradication of established murine tumors using a novel cell-free vaccine: dendritic cell-derived exosomes. Nat Med 1998, 4:594-600.
7. Johnstone RM, Adam M, Pan BT: The fate of the transferrin receptor during maturation of sheep reticulocytes in vitro. Can J Biochem Cell Biol 1984, 62:1246-1254.

8. Denzer K, van Eijk M, Kleijmeer MJ, Jakobson E, de Groot C, Geuze HJ: Follicular dendritic cells carry MHC class II-expressing microvesicles at their surface. J Immunol 2000, 165:1259-1265.

9. Hwang I, Shen X, Sprent J: Direct stimulation of naive T cells by membrane vesicles from antigen-presenting cells: distinct roles for CD54 and B7 molecules. Proc Natl Acad Sci USA 2003, 100:6670-6675.

10. Pelchen-Matthews A, Raposo G, Marsh M: Endosomes, exosomes and Trojan viruses. Trends Microbiol 2004, 12:310-316.

11. Heijnen HF, Schiel AE, Fijnheer R, Geuze HJ, Sixma JJ: Activated platelets release two types of membrane vesicles: microvesicles by surface shedding and exosomes derived from exocytosis of multivesicular bodies and alpha-granules. Blood 1999, 94:3791-3799.

12. Valadi $H$, Ekstrom $K$, Bossios A, Sjostrand M, Lee JJ, Lotvall JO: Exosomemediated transfer of mRNAs and microRNAs is a novel mechanism of genetic exchange between cells. Nat Cell Biol 2007, 9:654-659.

13. Gould SJ, Booth AM, Hildreth JE: The Trojan exosome hypothesis. Proc Natl Acad Sci USA 2003, 100:10592-10597.

14. Thery C, Zitvogel L, Amigorena S: Exosomes: composition, biogenesis and function. Nat Rev Immunol 2002, 2:569-579.

15. Raposo G, Moore M, Innes D, Leijendekker R, Leigh-Brown A, Benaroch $P$, Geuze H: Human macrophages accumulate HIV-1 particles in MHC II compartments. Traffic 2002, 3:718-729.

16. Leng Q, Bentwich Z, Magen E, Kalinkovich A, Borkow G: CTLA-4 upregulation during HIV infection: association with anergy and possible target for therapeutic intervention. Aids 2002, 16:519-529.

17. Pelchen-Matthews A, Kramer B, Marsh M: Infectious HIV-1 assembles in late endosomes in primary macrophages. J Cell Biol 2003, 162:443-455.

18. Nguyen DG, Booth A, Gould SJ, Hildreth JE: Evidence that HIV budding in primary macrophages occurs through the exosome release pathway. $J$ Biol Chem 2003, 278:52347-52354.

19. Kramer B, Pelchen-Matthews A, Deneka M, Garcia E, Piguet V, Marsh M: HIV interaction with endosomes in macrophages and dendritic cells. Blood Cells Mol Dis 2005, 35:136-142.

20. Chertova E, Chertov O, Coren LV, Roser JD, Trubey CM, Bess JW Jr, Sowder RC, Barsov E, Hood BL, Fisher RJ, et al: Proteomic and biochemical analysis of purified human immunodeficiency virus type 1 produced from infected monocyte-derived macrophages. J Virol 2006, 80:9039-9052.

21. Wiley RD, Gummuluru S: Immature dendritic cell-derived exosomes can mediate HIV-1 trans infection. Proc Natl Acad Sci USA 2006, 103:738-743.

22. Izquierdo-Useros N, Naranjo-Gomez M, Archer J, Hatch SC, Erkizia I, Blanco J, Borras FE, Puertas MC, Connor JH, Fernandez-Figueras MT, et al: Capture and transfer of HIV-1 particles by mature dendritic cells converges with the exosome-dissemination pathway. Blood 2009, 113:2732-2741.

23. Izquierdo-Useros N, Naranjo-Gomez M, Erkizia I, Puertas MC, Borras FE Blanco J, Martinez-Picado J: HIV and mature dendritic cells: Trojan exosomes riding the Trojan horse? PLoS Pathog 6:e1000740.

24. Jouvenet N, Neil SJ, Bess C, Johnson MC, Virgen CA, Simon SM, Bieniasz PD: Plasma membrane is the site of productive HIV-1 particle assembly. PLOS Biol 2006, 4:e435.

25. Gousset K, Ablan SD, Coren LV, Ono A, Soheilian F, Nagashima K, Ott DE, Freed EO: Real-time visualization of HIV-1 GAG trafficking in infected macrophages. PLoS Pathog 2008, 4:e1000015.

26. Garrus JE, von Schwedler UK, Pornillos OW, Morham SG, Zavitz KH, Wang HE, Wettstein DA, Stray KM, Cote M, Rich RL, et al: Tsg101 and the vacuolar protein sorting pathway are essential for HIV-1 budding. Cell 2001, 107:55-65.

27. Morita E, Sundquist WI: Retrovirus budding. Annu Rev Cell Dev Biol 2004, 20:395-425.

28. Coren LV, Shatzer T, Ott DE: CD45 immunoaffinity depletion of vesicles from Jurkat T cells demonstrates that exosomes contain CD45: no evidence for a distinct exosome/HIV-1 budding pathway. Retrovirology 2008, 5:64.

29. Ono A, Freed EO: Cell-type-dependent targeting of human immunodeficiency virus type 1 assembly to the plasma membrane and the multivesicular body. J Virol 2004, 78:1552-1563.

30. Jolly C, Sattentau QJ: Human immunodeficiency virus type 1 assembly, budding, and cell-cell spread in T cells take place in tetraspaninenriched plasma membrane domains. J Virol 2007, 81:7873-7884. 
31. Cantin R, Diou J, Belanger D, Tremblay AM, Gilbert C: Discrimination between exosomes and HIV-1: purification of both vesicles from cell-free supernatants. J Immunol Methods 2008, 338:21-30.

32. Booth AM, Fang Y, Fallon JK, Yang JM, Hildreth JE, Gould SJ: Exosomes and HIV Gag bud from endosome-like domains of the T cell plasma membrane. J Cell Biol 2006, 172:923-935.

33. Fang Y, Wu N, Gan X, Yan W, Morrell JC, Gould SJ: Higher-order oligomerization targets plasma membrane proteins and HIV gag to exosomes. PLoS Biol 2007, 5:e158.

34. Grigorov B, Arcanger F, Roingeard P, Darlix JL, Muriaux D: Assembly of infectious HIV-1 in human epithelial and T-lymphoblastic cell lines. J Mol Biol 2006, 359:848-862.

35. Bess JW Jr, Gorelick RJ, Bosche WJ, Henderson LE, Arthur LO: Microvesicles are a source of contaminating cellular proteins found in purified HIV-1 preparations. Virology 1997, 230:134-144.

36. Gluschankof P, Mondor I, Gelderblom HR, Sattentau QJ: Cell membrane vesicles are a major contaminant of gradient-enriched human immunodeficiency virus type-1 preparations. Virology 1997, 230:125-133.

37. Ott DE, Coren LV, Kane BP, Busch LK, Johnson DG, Sowder RC, Chertova EN, Arthur LO, Henderson LE: Cytoskeletal proteins inside human immunodeficiency virus type 1 virions. J Virol 1996, 70:7734-7743.

38. Thery C, Boussac M, Veron P, Ricciardi-Castagnoli P, Raposo G, Garin J, Amigorena S: Proteomic analysis of dendritic cell-derived exosomes: a secreted subcellular compartment distinct from apoptotic vesicles. J Immunol 2001, 166:7309-7318.

39. Thery C, Regnault A, Garin J, Wolfers J, Zitvogel L, Ricciardi-Castagnoli P, Raposo G, Amigorena S: Molecular characterization of dendritic cellderived exosomes. Selective accumulation of the heat shock protein hsc73. J Cell Biol 1999, 147:599-610.

40. Lancaster Gl, Febbraio MA: Exosome-dependent trafficking of HSP70: a novel secretory pathway for cellular stress proteins. J Biol Chem 2005, 280:23349-23355.

41. Liu Y, Shah SV, Xiang X, Wang J, Deng ZB, Liu C, Zhang L, Wu J, Edmonds T, Jambor C, et al: COP9-associated CSN5 regulates exosomal protein deubiquitination and sorting. Am J Pathol 2009, 174:1415-1425.

doi:10.1186/1743-422X-7-234

Cite this article as: Park and He: HIV-1 is budded from CD4+ T

lymphocytes independently of exosomes. Virology Journal 2010 7:234.

\section{Submit your next manuscript to BioMed Central and take full advantage of:}

- Convenient online submission

- Thorough peer review

- No space constraints or color figure charges

- Immediate publication on acceptance

- Inclusion in PubMed, CAS, Scopus and Google Scholar

- Research which is freely available for redistribution 